\begin{tabular}{ccc}
\hline & International Journal of Advanced Geosciences, 9(2) (2021) 99-109 \\
SPC & Website: www.sciencepubco.com/index.php/IJAG \\
Research paper & Resciences \\
\hline
\end{tabular}

\title{
Petrographic and geochemical study of Doua granitoids (adamawa-yade domain, center Cameroon): Petrogenesis and geodynamic implication
}

\author{
Amadou Diguim Kepnamou ${ }^{1 *}$, Naimou Seguem ${ }^{2}$, Ntoumbé Mama ${ }^{1}$, Amaya Adama Adama Dairou ${ }^{3}$, Bello \\ Bienvenu ${ }^{4}$, Haskandi Kalaza Josue ${ }^{4}$, Awé Wangmene Salomon ${ }^{5}$, Ngounouno Ismaila 1, 4 \\ ${ }^{1}$ Department of Mines Geology, School of Geology and Mining Ingeneering, University of Ngaoundere, Meiganga, Cameroon \\ ${ }^{2}$ Department of Geology, Faculty of Sciences and Technology, University Adam Barka of Abeché, Abeché, Tchad \\ ${ }^{3}$ Department of Geomatic and Geology Mapping, School of Geology and Mining Ingeneering, University of Ngaoundere, Meiganga, \\ Cameroon \\ ${ }^{4}$ Department of Earth Sciences, Faculty of Sciences, University of Ngaoundere, Ngaoundere, Cameroun \\ ${ }^{5}$ Mining Engineering Department, Saint-Jerôme Catholic University Institute in Douala, Douala, Cameroon \\ *Corresponding author E-mail: kepnamoudiguim@yahoo.fr
}

\begin{abstract}
The region Doua is located in the central area or Adamawa-Yade domain of the Pan-African fold belt in Cameroon. This work focuses on the petrography and geochemistry of granitoids in this region. The study area is made up of plutonic rocks (amphibole and biotite granite, biotite and muscovite granite, syeno-diorite, syenite. The geochemical study of the granitoids in the area shows that the rocks are magnesian and slightly iron-bearing, potassic to hyper-potassic calc - alkaline, metaluminous and belongs to type I granitoids. The profiles of the rare earths (REE) show a negative anomaly in Eu. The multi-element spectra show positive anomalies, or negative anomalies for some samples in $\mathrm{Ba}$ and Negative anomalies in $\mathrm{Nb}-\mathrm{Ta}$, Sr and Ti. The process which led to the formation of these rocks is fractional crystallization. These rocks are setup in a syn-collisional subduction environment (volcanic arc granitoids).
\end{abstract}

Keywords: Petrography; Geochemistry; Granitoids; Doua; Adamawa-Yade Domain; Pan-African Fold Belt of Central Africa

\section{Introduction}

Cameroon, a state in Central Africa, is a country made up at two-thirds of the Pan-African formations of the Central African Mobile Zone by [1], Pan-African fold belt of Central Africa, also called the North Equatorial Pan-African chain [2]. Pan-African fold belt of Central Africa extends over Cameroon, Chad, the Central African Republic (CAR) and Nigeria [3], [4]. It extends to the northeast of Brazil in the Borborema province [5 - 10]. The Pan-African fold belt of Central Africa can be divided into three domains: the northern Cameroon domain, the southern domain and the central domain (Adamawa-Yade), [11], [12] (fig. 1).

The central domain is the least studied of the three, and geological work is currently concentrated around three regions: i) the region of Bafia with the work of [13 - 15]; ii) the region of Tibati with; [16] ; [17] ; iii) the region of Meiganga with; [18], [19]. Apart these three regions, we can cite [20] in Ngaoundéré and [21] in the Touboro-Baïbokoum region.

The region of Doua which is the subject of this study belongs to the central domain (Adamawa-Yade) of the Pan-African fold belt of Central Africa. Previous petrographic and geochemical studies are often very local and limited to certain sector, generally separated by large areas unexplored or just little. These works are geological surveys essentially petrographic descriptions and very rare geochemical informations. The absence of detailed geochemical data and absolute geochronological data on the study area does not permit good correlations to be established with other works carried out in the Adamoua-Yade domain. Based on the latter, we have chosen to carry out the work in the region of Doua, a little explored area, in order to contribute to the knowledge of granitoids of the central domain (AdamawaYade) of the Pan-African fold belt in Cameroon in particular and looking for an evolution model of the Pan-African fold belt in Central Africa as a whole. 


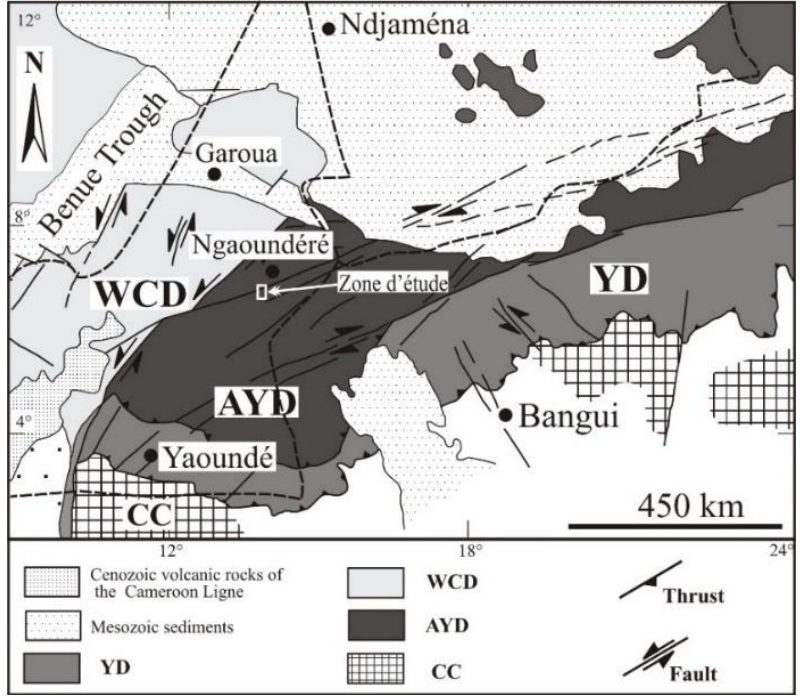

Fig. 1: Geological Sketch of the Pan-African Fold Belt North of the Congo Craton Showing the Study Area (Modified After [22]). WCD: West Cameroon Domain; AYD: Adamawa-Yade Domain; YD: Yaounde Domain.

\section{Geological setting}

In Cameroon, the pan-African belt is interpreted as a collisional belt by, [2]. Geological studies based on the structural analysis of the different deformation phases show that it was formed following a collision between the cratons of Congo-São Francisco, the West African craton and the Latéa and Saharan metacratons [23]. The Pan-African fold belt of Central Africa (CPAC) also called the North Equatorial pleated chain [2] is subdivided in Cameroon into three areas: southern domain, central domain and north domain; [17] (fig. 2).

The central domain to which the study area belongs is limited to the north by the Tcholiré-Banyo fault and to the south by the Sanaga fault over which overlaps the Yaoundé domain. The central domain continues in southern Chad and the Central African Republic to the Yade massif, thus the name "Adamawa -Yade" domain. This domain is a Paleoproterozoic basement established during the Pan-African orogeny ([9]; [22]) with the formation of sedimentary basins of the Lom series [24]. In central Cameroon, the Adamawa-Yade domain is characterized by an abundance of plutonic rocks, placed in Paleoproterozoic para- and orthoderivative gneisses, and acidic volcaniclastic rocks of the Lom series [25]. An age of 500-600 Ma was found for granitoids from the Adamawa-Yade domain [25], [26]. These are syn- to posttectonic granitoids ([20]; [27]) which, in the Meiganga and Tibati regions are associated with transcurrent fault zones ([16], [28]). They show similarities with plutons associated with shear zones in Borborema province in NE Brazil. The authors [29] highlight the geochemical and $207 \mathrm{~Pb} / 206 \mathrm{~Pb}$ age imprints of Archean imprints in the pyroxene and amphibole gneisses of Meiganga.

In this central domain, the granitoids are syn- to post-tectonic and of Pan-African age. These rocks are intrusive in the Paleoproterozoic basement and covered by Cretaceous sedimentary formations (Mbéré and Djérem basin) and Cenozoic volcanic formations [30]. They form a wide variety of rocks (amphibole and biotite granite, biotite and muscovite granite, biotite granite, gabbros, diorite, syeno-diorite and syenite). The granitoids in this domain are classified into syn-tectonic (630-610Ma), late tectonic (600-580Ma) and post-tectonic (550 Ma) granitoids ([13], [31]). In general, these granitoids are calc-alkaline and highly potassic to shoshonitic, metaluminous to slightly peraluminous, belonging to type I granitoids ([13], [16], [25], [32], [33]) and locally of type S ([31]; [32]). Isotopic data indicate that these granitoids are of crustal (Paleoproterozoic crust) or mixed origin, resulting from a mixture of juvenile mantelic source and Paleoproterozoic to Archean crust ([13], [25], and [33]).

\section{Methodology}

\subsection{Petrography}

The petrographic study began at the field scale and sample scale which allowed a macroscopic identification of the facies of the granitoids and the constituent minerals of each rock type. Thin sections of the rock samples were made at the Institute of Geology at the University of Tübingen in Germany, the University of Vienna in Austria and the Institute for Geological and Mining Research (IRGM) in Yaoundé, Cameroon.

\subsection{Geochemistry}

The major, trace and rare earth elements content of selected samples was determined by the ICP-AES (Inductively Coupled Plasma Atomic Emission Spectroscopy) quantification technique at ACME Analytical Laboratories (Vancouver, Canada). It was carried out by the alkaline fusion method of $200 \mathrm{mg}$ of each sample mixed with $900 \mathrm{mg}$ of lithium metaborate (LiBO2). The mixture is then dissolved in a solution of nitric acid (HNO3). The major elements, expressed as oxides, were determined by emission spectrometry while the trace elements by mass spectrometry.

\section{Results}

\subsection{Petrographic}

The Doua granitoids consist of granite (amphibole and biotite granite, biotite and muscovite granite), syeno-diorite and syenite, which are crocut by the pegmatite and quartzite veins. The explored outcrops are shown in figure 3. 


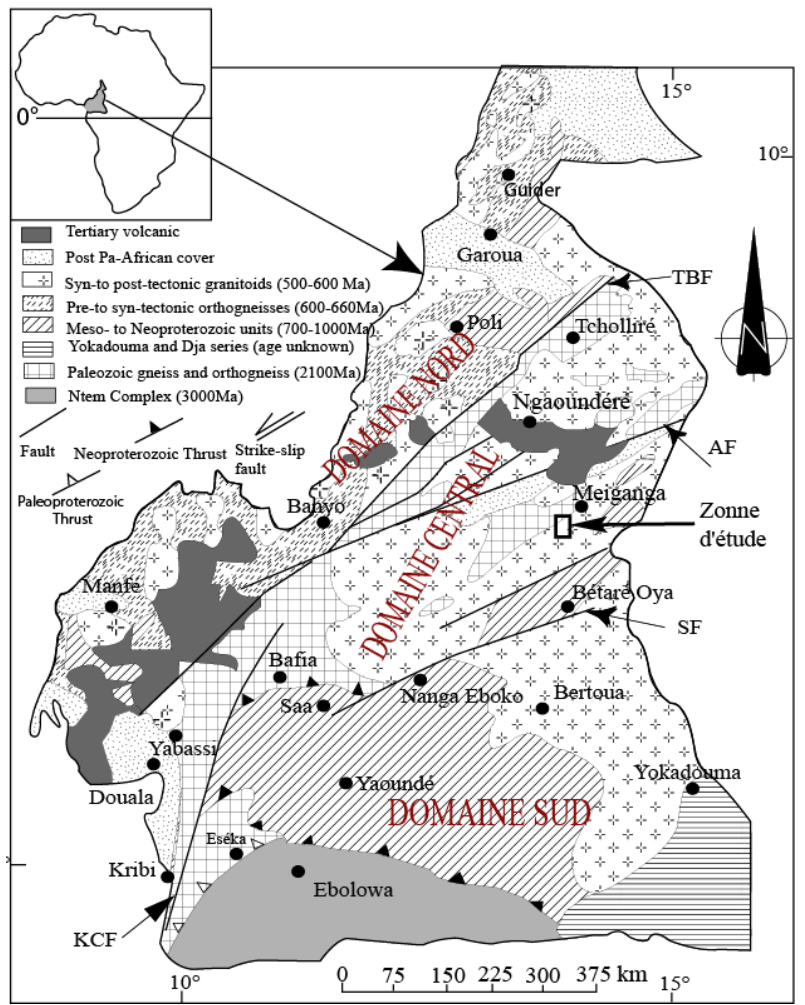

Fig. 2: Geological Map of Cameroon [13] Showing the Major Lithological Groups. AF, Adamawa Fault; KCF, Kribi - Campo Fault; SF, Sanaga Fault; TBF, Tcholliré - Banyo Fault. the Large Domains are [17] And [34]. the Study Area Is Represented by the Black Rectangle SW of Meiganga. Inset: Cameroon's Position in Africa.

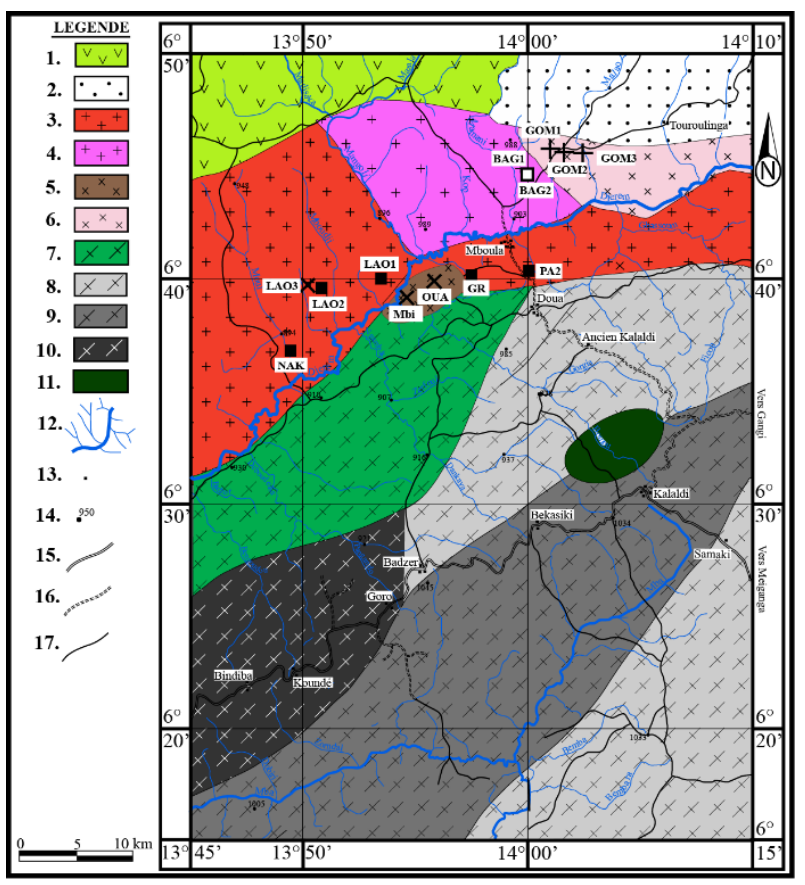

Fig. 3: Outcrop Map of the Doua Region. 1- Olivine Basalt; 2- Sandstone; 3- Amphibole and Biotite Granite; 4- Biotite And Muscovite Granite; 5- SyenoDiorite; 6- Syenite; 7- Orthogneiss; 8- Amphibole Gneiss; 9- Amphibole and Biotite Gneiss; 10- Biotite Gneiss; 11- Banded Amphibolite; 12- Hydrographic Network; 13-Villages; 14- Spot Height; 15- Main Road; 16- Secondary Road, 17- Track.

\subsubsection{Granite}

The classification of the different granites was made on the basis of essential minerals. It made it possible to distinguish: amphibole and biotite granite and biotite and muscovite granites.

\subsubsection{Amphibole and biotite granites}

The amphibole and biotite granite crops out as slabs and blocks in the river bed and banks of the Mbappa stream to the north of Doua. The amphibole-biotite granite sometimes contains amphibolite enclaves (Fig. 4a). The amphibole biotite granite has a coarse grain texture (fig. $4 \mathrm{~b}$ ) and consists of amphibole, biotite, quartz, plagioclase, orthoclase, microcline, chlorite, sphene, zircon, apatite, and opaque minerals. Amphibole contains inclusions of quartz, biotite, zircon and opaque minerals (Fig. 4c). 


\subsubsection{Biotite and muscovite granite or two-mica granite}

The biotite and muscovite granite forms two hills (Deugbelia and Baggo) which is over the savannah north of Doua village. On this Bagge hill, there is a cracked block at the top of the hill (fig. 4d). The rock has a granular porphyritic texture. The phenocrysts are formed of feldspar (4 to $6 \mathrm{~mm}$ ) in a grainy matrix (fig. 4e) made up in addition to biotite, muscovite, quartz, plagioclase, orthose, microcline, chlorite. Accesory minerals include zircon and opaque minerals. Muscovite forms flakes of almost identical size to biotite flakes. Muscovite is associated with quartz, feldspar and sometimes biotite (Fig. 4f). K-feldspar is made up of orthoclase and microcline.

\subsubsection{Syeno-diorite (monzonite)}

Syeno-diorite crops out as slabs (fig. $4 \mathrm{~g}$ ) on a hill west of Doua village. Syeno-diorite (monzonite) has a granular texture (fig. 4h) and consists of amphibole, biotite, quartz, plagioclase, orthose, microcline, chlorite, zircon, apatite, and opaque minerals. Plagioclase forms crystals of 0.5 to $1 \mathrm{~mm}$ long averagely, sub-automorphic in shape and exibits double twinning (Carslbad and polysynthetics) (fig. 4h). Plagioclase is associated with biotite and quartz in the rock.

\subsubsection{Syenite}

The syenite forms elongated ENE-WSW hills north of Doua village. The rock has a gray color with a dark gray patina. The rock crops out in the form of a slab at the top of the hills. The rock shows a grainular texture. It is made up of amphibole, biotite, plagioclase, orthosis, apatite, zircon and opaque minerals. Amphibole is a green hornblende varying in size from 1 to $3 \mathrm{~mm}$, automorphic to sub-automorphic. The basal section of the amphibole has a hexagonal shape (Fig. 4i). Amphibole contains inclusions of apatite, feldspar, zircon, and opaque minerals.
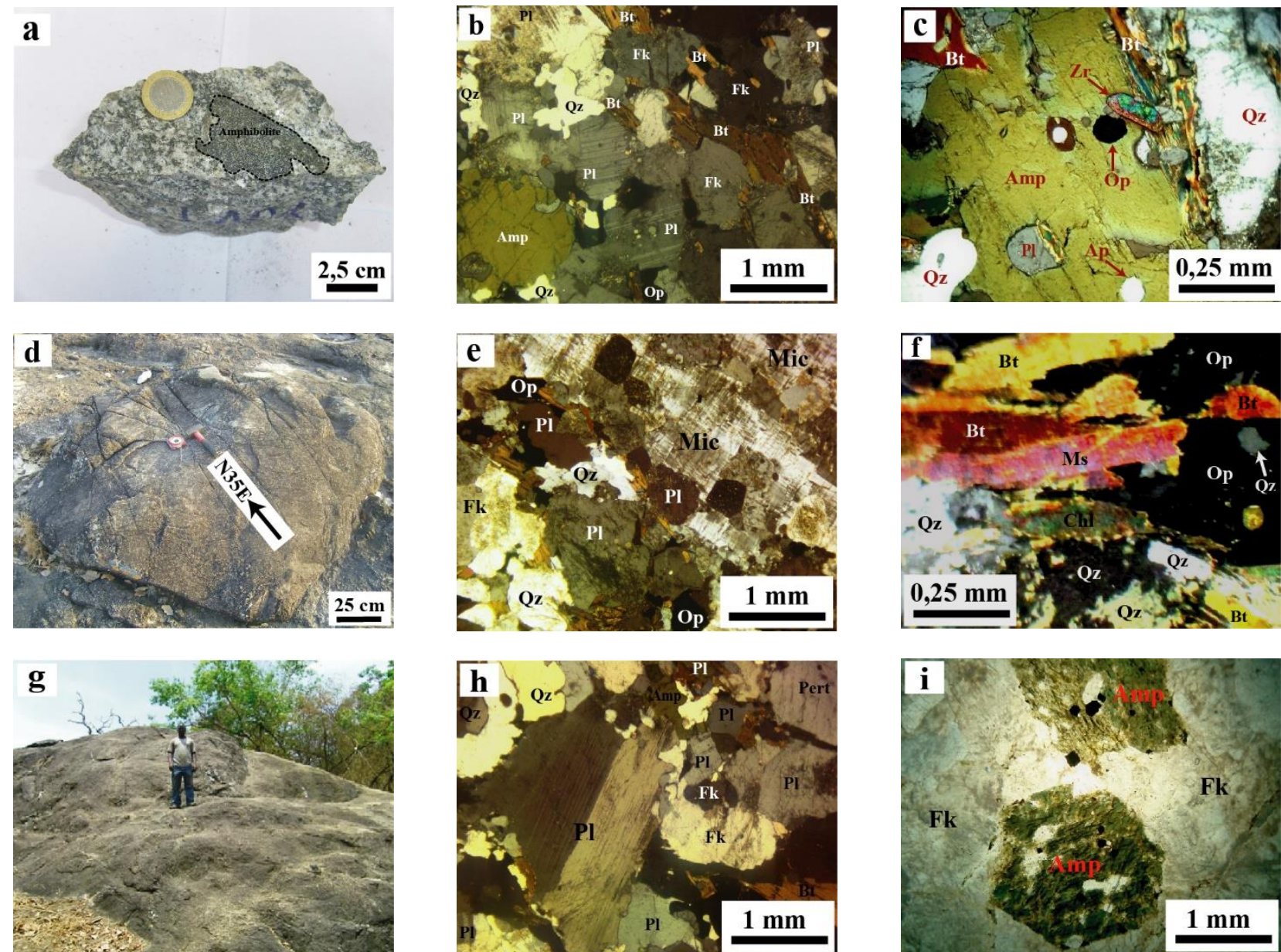

Fig. 4: A- Amphibole and Biotite Granite Sample Showing an Amphibolite Enclave; B- Coarse Texture of Amphibole and Biotite Granite in LPA; CAmphibole with Inclusion of Apatite, Zircon and Opaque in PL; D- Cracked Block of Biotite and Muscovite Granite Located on the Top of the Baggo Outcrop; E- Porphyritic Granite Texture of Biotite and Muscovite Granite in PL; F- Muscovite Flakes Associated with Biotite Flakes and Opaque Minerals (LPA); G- Syeno-Diorite Slab Outcrop; H- Sub-Automorphic Plagioclase Crystal with Double Twins (LPA) in Syeno-Diorite; I- Basal Section of Amphibole with Inclusion of Apatite, Feldspars and Opaque Minerals in LPNA in the Syenite.

\subsection{Geochemical study}

\subsubsection{Classification and nomenclature}

Classification diagram of [35], adapted to plutonic rocks by [36], was used to discriminate the studied rock samples (fig. 5). The rocks of the region form a sequence ranging from syeno-diorite to granite, passing through granodiorite and syenite. The samples of syeno-diorite and syenite fall in the domain of alkaline rocks, while the samples of granite fall in the field of sub-alkaline rocks. 


\subsubsection{Geochemical characterization}

The plutonic rocks of the Doua region are characterized by a variation in weight of the oxides: $52.21-73.34 \%$ of $\mathrm{SiO} 2 ; 13.37-17.77 \%$ $\mathrm{A} 12 \mathrm{O} 3 ; 2.56$ - 5.98\% K2O; 0.14 - 09.16\% Fe2O3; 3.34 - 4.78\% Na2O; 0.95 - 5.87\% CaO; 0.22 - 5.00\% MgO; 0.20 - $1.74 \% \mathrm{TiO} 2$ and 0.13 $-1.74 \% \mathrm{P} 2 \mathrm{O} 5$. The sum of the alkalis $(\mathrm{Na} 2 \mathrm{O}+\mathrm{K} 2 \mathrm{O})$ varies between 7.21 and $9.90 \%$ and the $\mathrm{K} 2 \mathrm{O} / \mathrm{Na} 2 \mathrm{O}$ ratio varies between 0.56 and 1.85. Overall, the plutonic rocks are characterized by medium to high $\mathrm{Ba}(1087-3098 \mathrm{ppm})$, low to medium $\mathrm{Sr}(102.4-1707 \mathrm{ppm})$ and low $\mathrm{Rb}(74.8-297.5 \mathrm{ppm})$ contents.

In the $\mathrm{K} 2 \mathrm{O}$ vs $\mathrm{SiO} 2$ diagram of [37] (fig. 6a), the plutonic rocks analyzed falls within the potassic calc-alkaline and hyperpotassic granitoids field. Two (02) samples of syenite in the shoshonitic series, close to the limit with the hyperpotassic calc-alkaline series.

The A / NK versus A / CNK diagram of [39] (fig. 6b) indicates an $\mathrm{Al}_{2} \mathrm{O}_{3} /\left(\mathrm{Na}_{2} \mathrm{O}+\mathrm{K}_{2} \mathrm{O}\right)$ or A / NK molar ratio which varies between 1.03 and 2.06 and an $\mathrm{Al} 2 \mathrm{O} 3$ / molar ratio. $\left(\mathrm{CaO}+\mathrm{Na}_{2} \mathrm{O}+\mathrm{K}_{2} \mathrm{O}\right)$ or $\mathrm{A} / \mathrm{CNK}$ less than 1.1 (0.68 to 1.07). This diagram shows that the Doua granitoids are mostly metaluminous in nature with the exception of three samples (03) amphibole and biotite granites which fall in the peraluminous domain. All samples belong to the domains of type I granitoids.

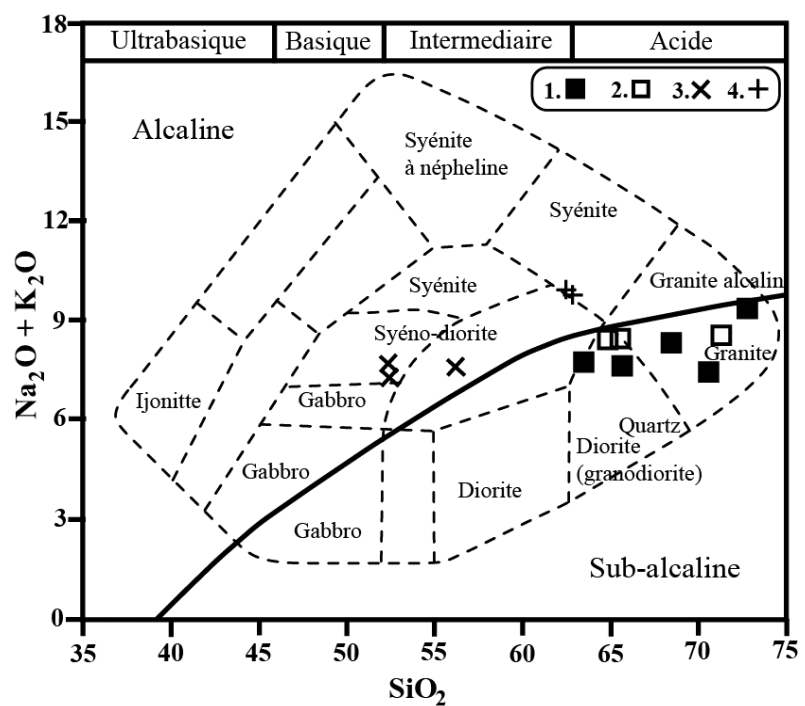

Fig. 5: Classification of Plutonic Rocks of Doua Region on the Diagram of [35], Adapted to Plutonic Rocks by [36]. the Bold Line Limits the Fields of Alkaline and Sub-Alkaline Rocks. 1. Amphibole and Biotite Granite; 2. Biotite and Muscovite Granite; 3. Syeno-Diorite; 4. Syenite.
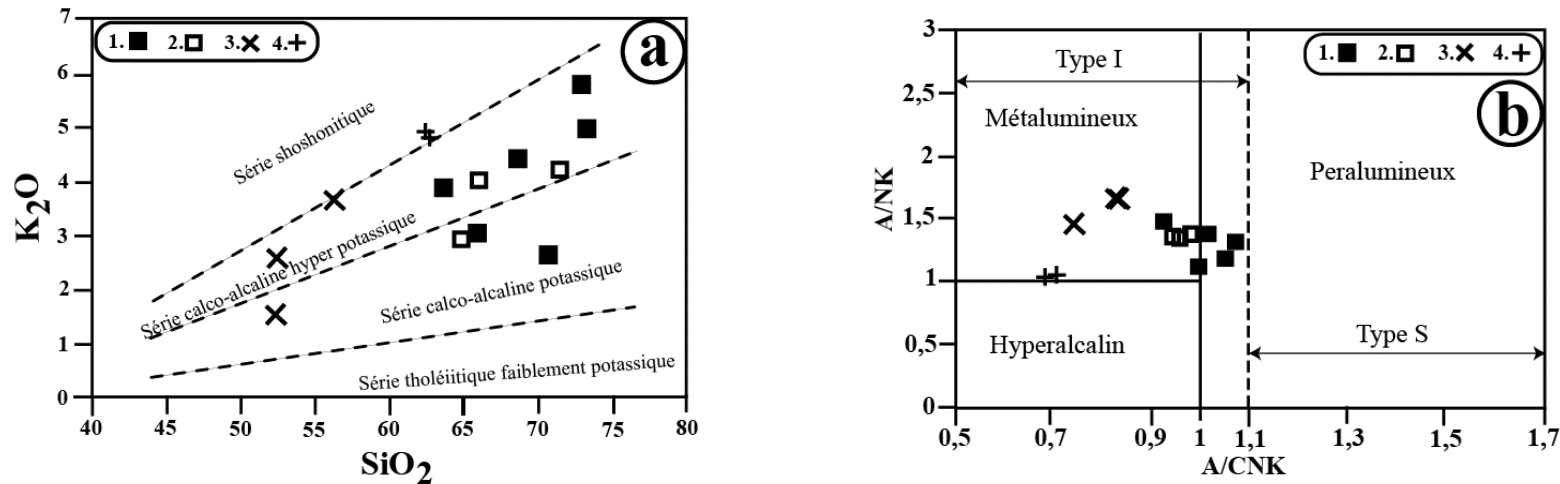

Fig. 6: $\mathrm{A}-\mathrm{K}_{2} \mathrm{O}$ Diagram on $\mathrm{Sio}_{2}$ to Discriminate the Granitoids of Doua Region. the Limits of the Series Are [37]; B- Positions of Plutonic Rocks of the Locality of Doua in the Diagram of [38]. A / NK $=\mathrm{Al}_{2} \mathrm{O}_{3} /\left(\mathrm{Na}_{2} \mathrm{O}+\mathrm{K}_{2} \mathrm{O}\right)$; $\mathrm{A} / \mathrm{CNK}=\mathrm{Al}_{2} \mathrm{O}_{3} /\left(\mathrm{CaO}+\mathrm{Na}_{2} \mathrm{O}+\mathrm{K}_{2} \mathrm{O}\right)$ in Mole. the Boundaries between $\mathrm{Granites}$ I and S Are from Chappell and White (1992). 1. Amphibole and Biotite Granite; 2. Biotite and Muscovite Granite; 3. Syeno-Diorite; 4. Syenite.

\subsubsection{Geochemical evolution}

The geochemical evolution is based on major, trace and rare earths elements.

\subsubsection{Major and trace elements}

In Harkers diagram [39] (fig. 7), the representative points of the plutonic rocks of Doua region show a decrease in $\mathrm{Fe}_{2} \mathrm{O}_{3}, \mathrm{Al}_{2} \mathrm{O}_{3}, \mathrm{MgO}$, $\mathrm{CaO}, \mathrm{TiO}_{2}$ and $\mathrm{P}_{2} \mathrm{O}_{5}$ with the increase of $\mathrm{SiO}_{2}$ content. $\mathrm{Na}_{2} \mathrm{O}$ and $\mathrm{K}_{2} \mathrm{O}$ vary little and show no correlation with $\mathrm{SiO}_{2}$. Harker's diagrams of some trace elements as a function of silica (fig. 8) show a dispersion of representative plots of rock samples from the study area for Ba, $\mathrm{Rb}, \mathrm{Sr}, \mathrm{Zr}, \mathrm{Nb}, \mathrm{Ta}$ and $\mathrm{Y}$ with increasing silica. The V - SiO2 diagram shows a linear regression with increasing $\mathrm{SiO} 2$ content. 


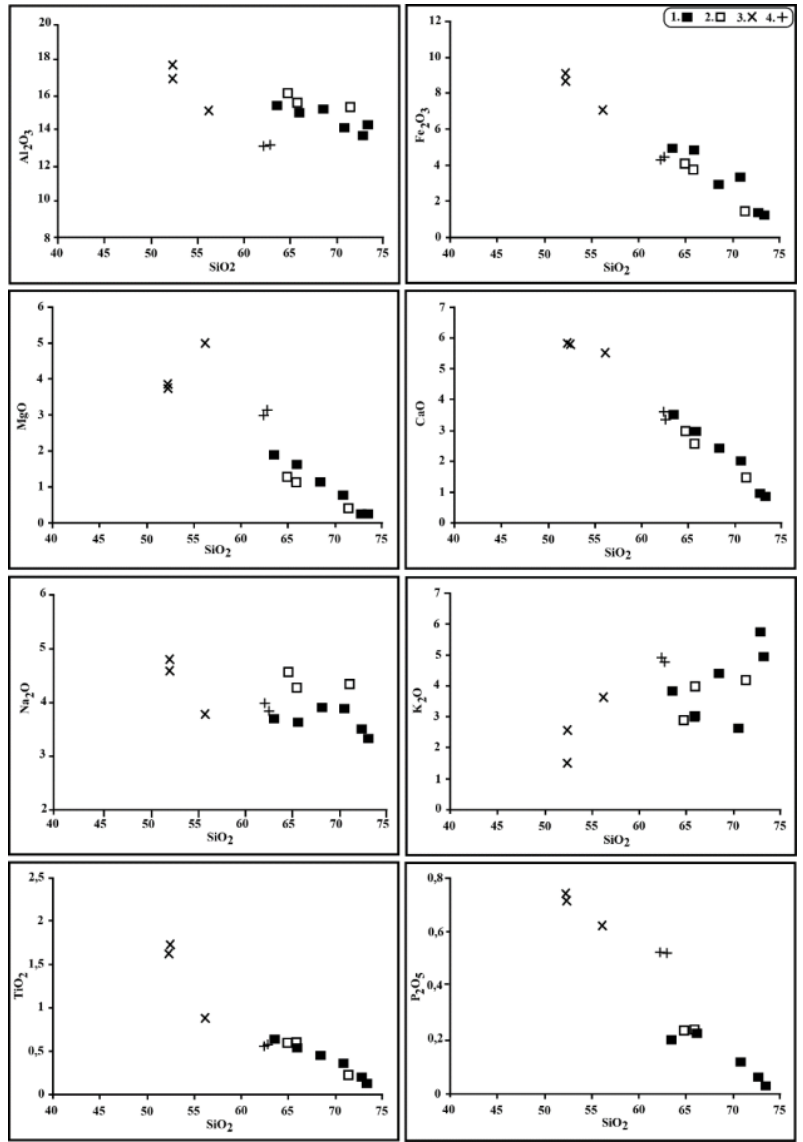

Fig. 7: Harker's Diagram of the Granitoids of Doua Region, Showing the Variation of Oxides as A Function of Sio2. 1. Amphibole and Biotite Granite; 2. Biotite and Muscovite Granite; 3. Syeno-Diorite; 4. Syenite.

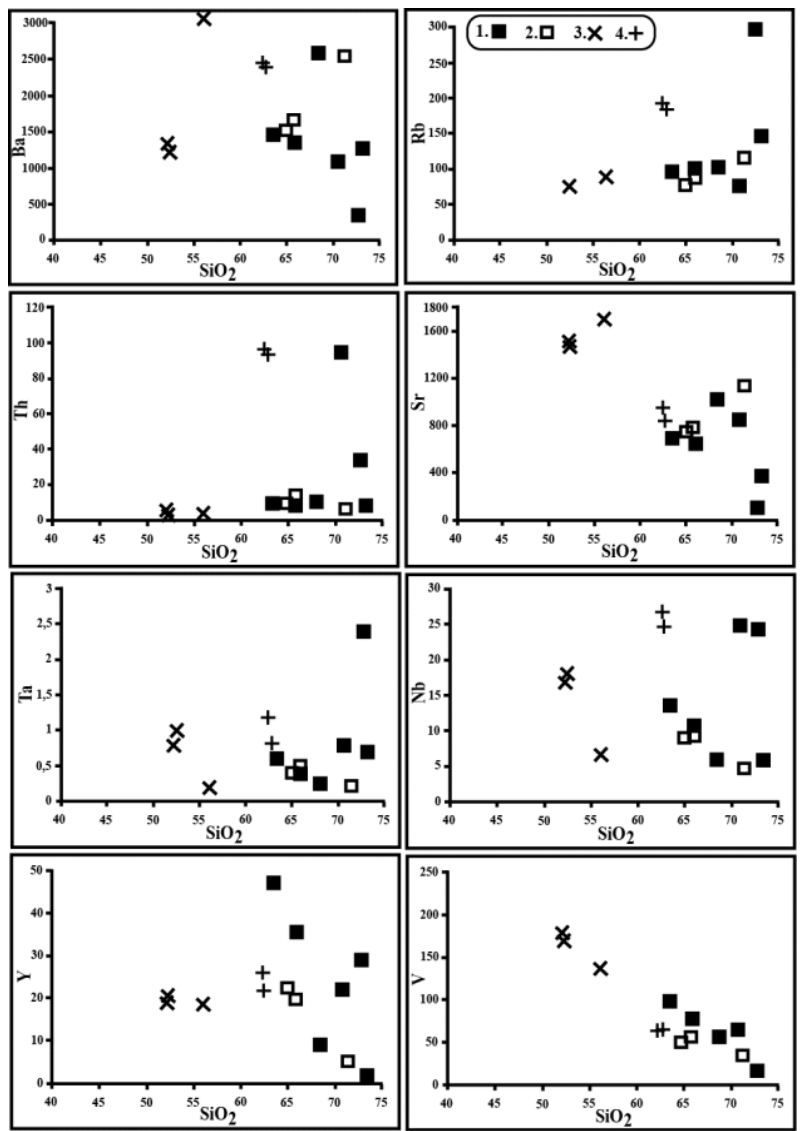

Fig. 8: Harker's Diagram of Some Trace Elements of Granitoids from the Doua Region. 1. Amphibole and Biotite Granite; 2. Biotite and Muscovite Granite; 3. Syeno-Diorite; 4. Syenite. 


\subsubsection{Rare earths (REE)}

The rare earth spectra normalized to chondrites according to the values of [40] of the Doua granitoids (fig. 9) are characterized by their high content of light rare earths elements (LREE) compared to heavy rare earths (HREE). Rare earth spectra of amphibole and biotite granites (Fig. 9a) show strong fractionation $[(\mathrm{La} / \mathrm{Yb}) \mathrm{N}=08.09$ - 49.96] and almost flat profile segments of heavy rare earth elements (HREE) $[(\mathrm{Gd} / \mathrm{Lu}) \mathrm{N}=1.61$ - 3.68]. The samples PA1, PA2 and GR show profiles with negative anomaly in $\mathrm{Eu}(\mathrm{Eu} / \mathrm{Eu} *=0.64 ; 1.38$ and 0.55$)$ meanwhile the samples LAO1, LAO3 and NAK show no anomaly in Eu (Eu / $\mathrm{Eu} *=1.05 ; 0.88$ and 0.82$)$.

The spectra of the biotite and muscovite granites (fig. 9b), show high fractionation [( $\mathrm{La} / \mathrm{Yb}) \mathrm{N}=21.76-49.90]$ and spectra segments almost flat for heavy rare earths elements $[(\mathrm{Gd} / \mathrm{Lu}) \mathrm{N}=2.89-4.02]$. There is a negative Eu anomaly $(\mathrm{Eu} / \mathrm{Eu} *=0.72-0.91)$ for samples BAG1 and BAG3 and no Eu anomaly for sample BAG2.

The syeno-diorite and syenite samples show rare earth elements spectra (fig. 9c and 9d) with strong fractionation $[(\mathrm{La} / \mathrm{Yb}) \mathrm{N}=19.16-$ 32.11]. The segments of the heavy rare earth element spectra are almost flat $[(\mathrm{Gd} / \mathrm{Lu}) \mathrm{N}=2.94-4.64]$. These spectra show no anomaly in Eu.

The multielement spectra of Doua granitoids normalized to the primitive mantle (fig. 10) show their richness in LILE (Large Ion Lithophile Element) compared to HFSE (High Field Strengt Element). Samples of the amphibole and biotite granite (fig. 10a) show spectra with a negative anomaly in Ta-Nb and Ti. The sample profiles show a positive Ba anomaly with the exception of the GR sample. The GR sample shows a negative anomaly in $\mathrm{Ba}$ and $\mathrm{Sr}$, while the NAK sample shows a positive anomaly in $\mathrm{Sr}$. For the biotite and muscovite granite, the multi-element spectra of figure $10 \mathrm{~b}$ show a negative anomaly in $\mathrm{Ta}-\mathrm{Nb}$, Ti and a positive anomaly in Ba. Sample BAG2 shows a positive anomaly in Sr. The multi-element spectra of Syeno-diorite (fig. 10c), show profiles with a positive anomaly in Ba and $\mathrm{Sr}$ and negative in $\mathrm{Ta}-\mathrm{Nb}$ and $\mathrm{Ti}$. The multi-element spectra of the syenite (fig. 10d) show profiles with a positive anomaly in Ba and negative in Ta-Nb and $\mathrm{Ti}$.
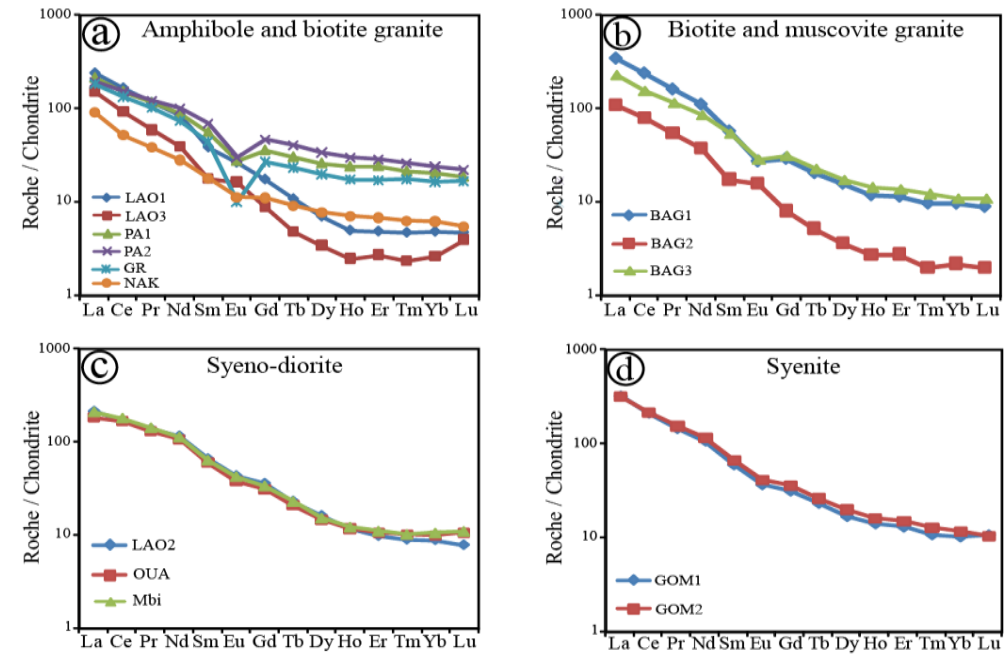

Fig. 9: Rare Earth Element Spectra of Plutonic Rocks from the Doua Region Normalized to Chondrites [40].
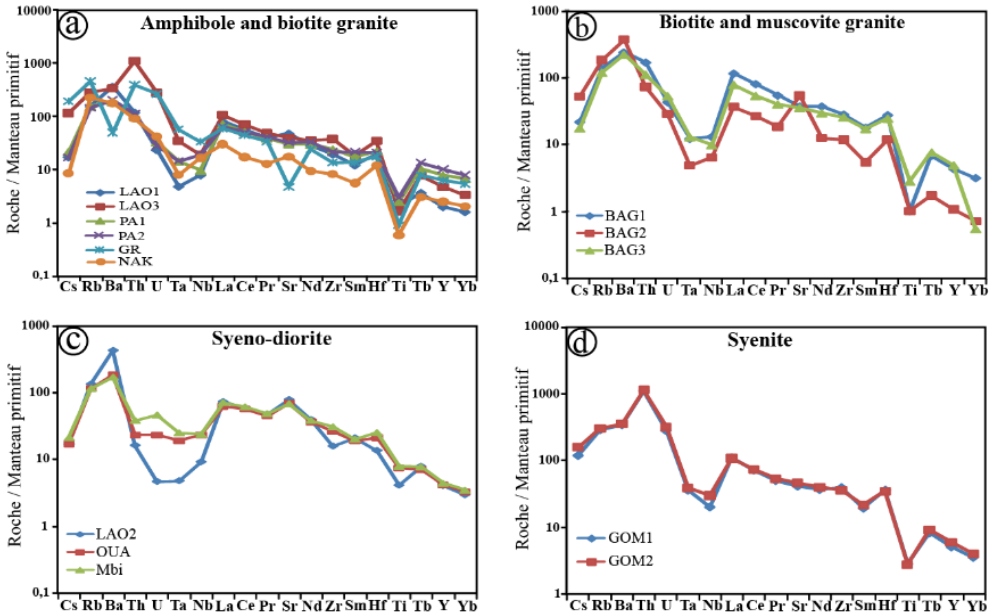

Fig. 10: Multi-Element Spectra of Doua Granitoids Normalized to the Values of [40].

\subsubsection{Magmatic tendency and geodynamic context}

\subsubsection{Magmatic tendency}

In the $\mathrm{FeO}^{\mathrm{t}} / \mathrm{MgO}$ versus $\mathrm{SiO}_{2}$ diagram of [41] (Fig. 11a), the rock sample rocks fall into two domains: tholeiitic and calc-alkaline. One sample of biotite amphibole granite and two samples of monzonite falls in the tholeiitic domain. The remaining samples (02) amphibole and biotite granites, two (02) biotite and muscovite granites, one (01) syeno-diorite and the two (02) syenites are found in the calc-alkaline domain. This disposition is confirmed in the triangular diagram FeOt / Na2O + $\mathrm{K} 2 \mathrm{O} / \mathrm{MgO}$ of [42] (fig. 11b).

In the diagram $\mathrm{FeO} /(\mathrm{MgO}+\mathrm{FeO})$ as a function of $\mathrm{SiO} 2$ of [43] (fig. 12), studied samples rocks are mainly magnesian with the exception of two (02) amphibole granite samples which fall in the iron field. 

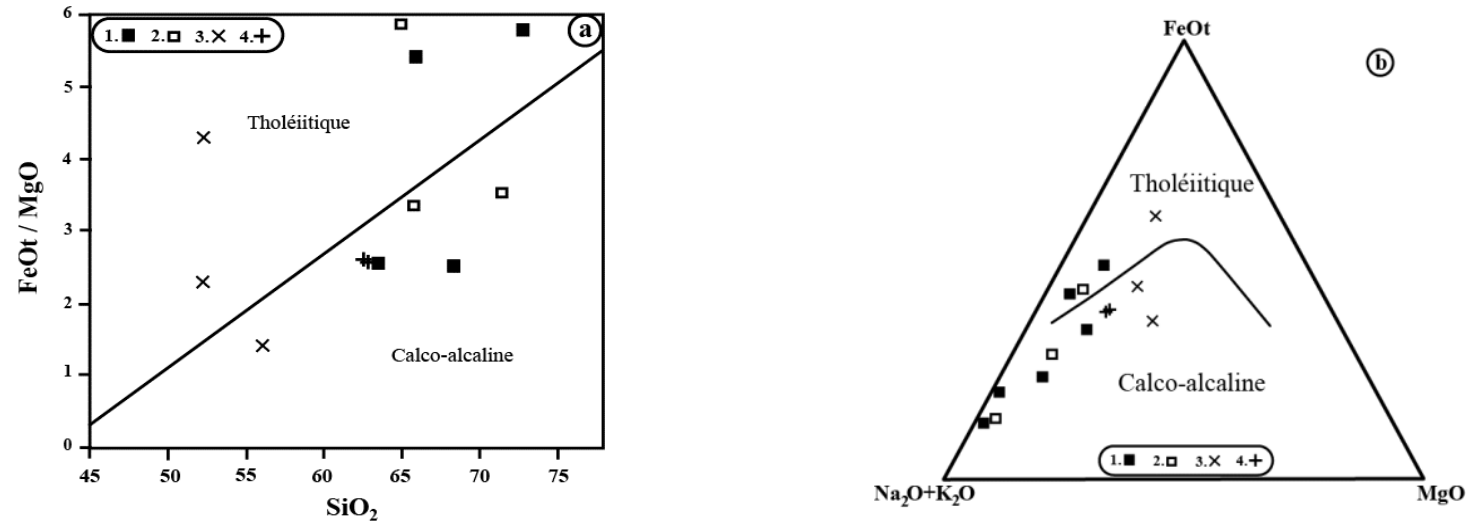

Fig. 11: A- Position of Rocks in the Doua Region in the Feot / Mgo Diagram as A Function of Sio2, According to [41]; B- Position of Rocks of the Doua Region in the Triangular Diagram Feot / Na2O + K2O / Mgo) of Irvine and Barragar [42] Showing the Tholeiitic and Calc Alkaline Domain. 1. Amphibole and Biotite Granite; 2. Biotite and Muscovite Granite; 3. Syeno-Diorite; 4. Syenite.

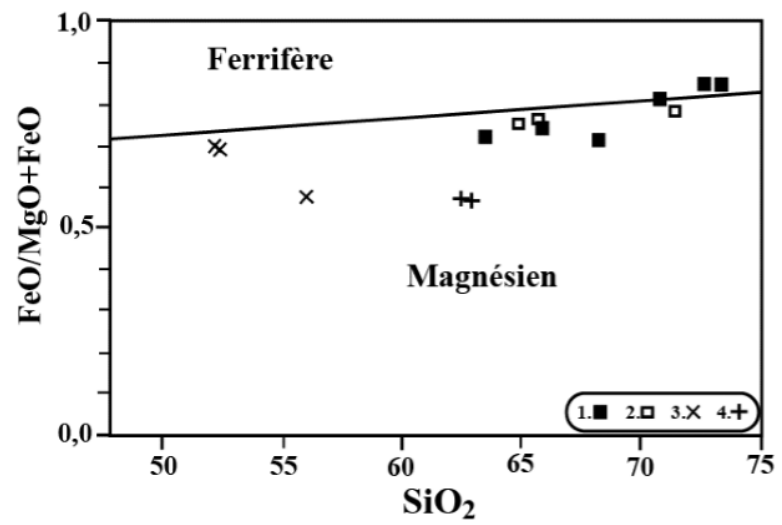

Fig. 12: Position of the Doua Granitoids in the Feo / (Mgo + Feo) Diagram as A Function of Sio2 from [43], Showing the Iron and Magnesium Domain. 1. Amphibole and Biotite Granite; 2. Biotite and Muscovite Granite; 3. Syeno-Diorite; 4. Syenite.

\subsubsection{Geodynamic context}

Several works have been carried out with the aim of establishing a direct link between the chemical composition of plutonic rocks and the geodynamic context of their setting in place. This made several authors to use the composition of rock in major elements and traces elements. In the $\mathrm{Nb}$ versus Y diagram of [44] (fig. 13a), the rock samples are mostly in the VAG + Syn-COLG field with the exception of two (02) samples of amphibole and biotite granites, two (02) samples of amphibolites which fall inbetween the domain of intraplate granitoids and ocean ridge granitoids and as well as two (02) samples of syenites which fall at the limit of intraplate granitoids and the overlap field. On the other hand, all the samples are in the domain of volcanic arc granitoids (VAG) in the diagram of [45] (fig. 13b).
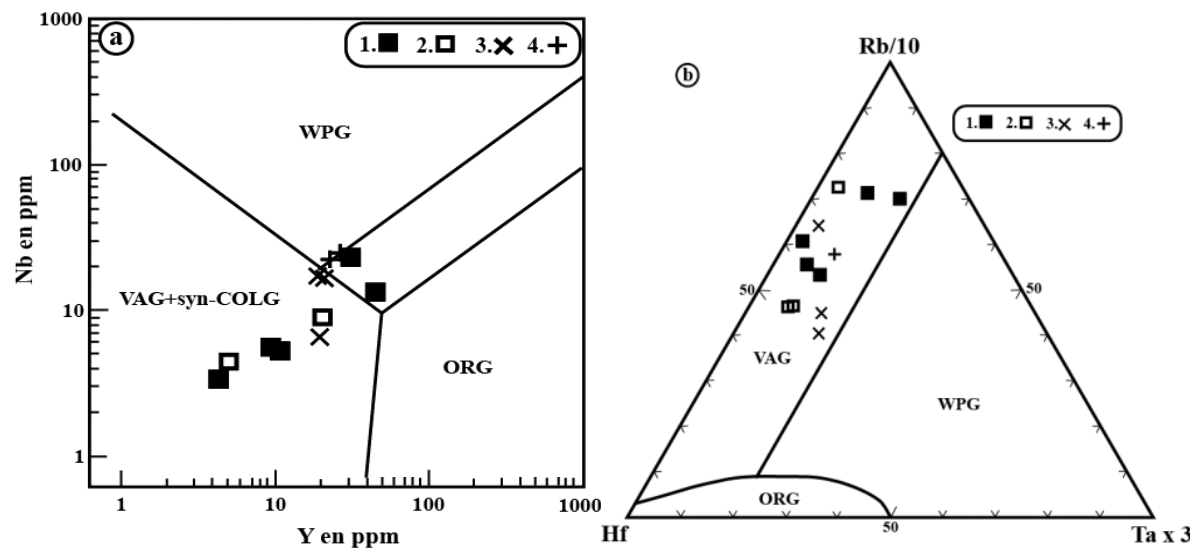

Fig. 13: A- Position of the Granitoids of Doua Region in the Tectono-Discriminant Diagram of Y As a Function of Nb (in Ppm) Of [44]; B- Discrimination Diagram of the Geotectonic Setting After [45], Showing the Position of the Doua Granitoids. (VAG + Syn-COLG: Volcanic to Syn-Collisional Arc Granitoids; VAG: Volcanic Arc Granitoids; WPG: within Plate Granitoids; ORG: Oceanic Ridge Granitoids). 1. Amphibole and Biotite Granite; 2. Biotite and Muscovite Granite; 3. Syeno-Diorite; 4. Syenite.

\section{Discussion}

Doua granitoids have a grainular texture, to porphyritic texture and have the following order of crystallization of minerals: zircon - apatite - sphene - amphibole - plagioclase - biotite - microcline - orthoclase - muscovite - quartz. Granitoids of the same or similar composition are described in several areas of the Adamawa-Yade domain. We can mention the regions of Banyo [17], Ngaoundéré [31], Bafoussam [32]). The pyroxene, amphibole and biotite granite described at Mbaïbokoum [21] is absent in our study area. This pyroxene, amphibole and biotite granite could be the equivalent of the amphibole and biotite granite of Doua. 
The nomenclature of the rocks of Doua classifies the samples in the fields of granitoids made up of granite, syeno-diorite, syenite, diorite and granodiorite (see fig. 5). These rocks are potassic calc-alkaline to hyperpotassic, magnesian to slightly iron-bearing (cf. fig. 6a), metaluminous and belonging to type I granitoids (cf. fig. 6b). Rocks with the same characteristics have been described in several sectors of the Adamawa-Yade domain of the Pan-African fold belt of Central Africa [21]; [32].

The distribution of the major elements in the Harker diagram with a negative linear correlation between $\mathrm{SiO} 2$ and the oxides $\mathrm{Al} 2 \mathrm{O} 3, \mathrm{MgO}$, $\mathrm{Fe} 2 \mathrm{O} 3, \mathrm{CaO}, \mathrm{MnO}, \mathrm{TiO} 2$ and $\mathrm{P} 2 \mathrm{O} 5$, reflects the involvement of fractional crystallization ([46]; [47]). The decreases in $\mathrm{Fe} 2 \mathrm{O} 3$, $\mathrm{MgO}$ and $\mathrm{MnO}$ reflect the fractional crystallization of the first ferromagnesian silicate minerals and that of titanium oxides [48]. As for the decrease in $\mathrm{CaO}$ and $\mathrm{Al2O} 3$, it is related to the crystallization of plagioclase [49]. The approximately linear distribution of the elements also reflects the involvement of fractional crystallization or mixing processes between mafic and felsic magmas ([46]; [50]).

Light rare earth elements (LREE) enrichment (cf. fig. 9) indicates fractionation of accessory minerals such as apatite, while a depletion in heavy rare earth elements (HREE) is attributed to zircon fractionation [51]. The negative Eu anomaly observed for most of the rocks studied reflects the fractionation of plagioclase during the evolution of the parent magma [52].The absence of negative Eu anomaly in syeno-diorite and syenite (cf. fig. 9c and 9d) despite the presence of plagioclase in these rocks can be explained by the fact that Eu may have not been incorporated into the plagioclase and may reflect strong oxidative conditions with all Eu is in the form of $\mathrm{Eu}^{3+}$ or limited fractionation of plagioclase in the source [53]. This observation was also made for the granites of Mbip by [54]. The abundance of ferromagnesian minerals such as amphibole in the rocks suggests on one hand that the fusion that took place has a magmatic source of mantle origin [55]. The global parallelism of the profiles of rare earths elements indicates that these rocks are cogenetic ([56]; [57]). The high negative anomalies in NbTa on the profil of these rocks are classically interpreted as corresponding to the characteristics of rocks originating from the continental crust ([58]; [59]). The negative Ti anomaly would indicate crystallization ferro-titanium minerals. The opaque minerals observed in these rocks would then be ferro-titanium. The positive Sr anomaly in some spectra may be related to the high proportion of plagioclase in these rocks [52]. Note that with few exceptions, all the rocks studied show a negative anomaly in $\mathrm{Ta}-\mathrm{Nb}, \mathrm{Sr}$ and $\mathrm{Ti}$, and sometimes a positive anomaly in Ba. These are the characteristics of rocks of crustal origin. It is not excluded that the biotite and muscovite granite of Doua, is an S type granitoid. Its position in the field of I type granitoids, would only be the reflection of contamination by mantellic material. Granitoids recognized as S type and exhibiting the same characters have been described in the region of Bafoussam [32].

Synthetic multielement spectra of Doua granitoids normalized to the primitive mantle of [40] were carried out. The comparison between the granitoids of the study area and those of Ngaoundéré [31], Bafoussam [32] and Mbip [54] is highlighted on figure 14. On this diagram, the profiles of the granitoids of Doua present a parallelism with the fields which delimit the granitoids of Ngaoundéré, Bafoussam and Mbip, which allows us to conclude that the granitoids of our study area integrate the field of granitoids from the Adamawa-Yade domain in Cameroon.

The potassic calc-alkaline to highly potassic and tholeiitic character of the studied rocks and the negative anomaly in $\mathrm{Ta}-\mathrm{Nb}$ and $\mathrm{Ti}$ are compatible with a geodynamic environment of continental collision leading to subduction [60]. In general, strongly potassic calc-alkaline granitoids suggests a tectonic environment of continent-continent collision or volcanic arc ([51]; [61]; [62]). The geochemical characteristics of the studied granitoids are also comparable to those of many pan-African syn- to late-tectonic granitoids studied in the central domain of the Pan-African fold belt chain in Cameroon ([31]; [32]; [15]; [63]; [21]; [54]). The emplacement of these granitoids in this domain is linked to a collision in relation to the northern margin of the Adamawa-Yade domain and the northern domain ([31]; [64]).

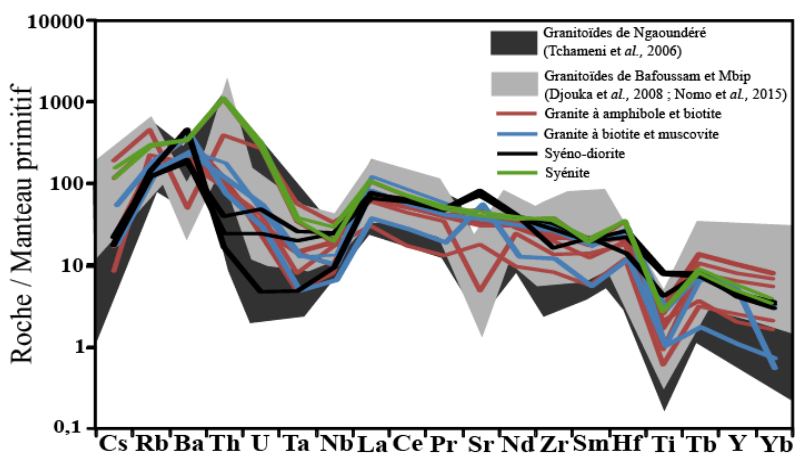

Fig. 14: Multi-Element Spectra of Granitoids from the Doua Region Normalized to the Values of [40].

\section{Conclusion}

Doua granitoids consist of amphibole and biotite granite; biotite and muscovite granite; syeno-diorite and syenite. These rocks have a granular to porphyritic texture. Primary minerals are made up of $\mathrm{Amp}+\mathrm{Bt}+\mathrm{Pl}+\mathrm{Ort}+\mathrm{Mic}+\mathrm{Qz}+\mathrm{Ap}+\mathrm{Sph}+\mathrm{Zr}$ and secondary minerals are made up of $\mathrm{Ep}+\mathrm{Chl}+\mathrm{Ser}+\mathrm{Op}$. The geochemistry of these granitoids show that these rocks form a sequence ranging from syenodiorite to granite and syenite. These slightly iron-bearing magnesian rocks, potassic calc-alkaline to highly potassic, metaluminous and belong to I type granitoids, which underwent the process of fractional crystallization in their setting in place. Doua granitoids have at various intensities a negative anomaly in Eu. They are rocks of crustal origin with addition of mantellic material, or mantle source rocks with addition of crustal material (negative anomaly in $\mathrm{Ta}-\mathrm{Nb}, \mathrm{Sr}$ and $\mathrm{Ti}$ ). They are set up in a subduction to syn-collisional environment (volcanic arc granitoids).

\section{Thanks}

The authors thank the anonymous reviewers for their contributions which improve the quality of the manuscript.

\section{References}

[1] Bessoles B., Trompette R., 1980. Géologie de l'Afrique. La chaine panafricaine « zone mobile de l'Afrique (partie Sud) et zone mobile Soudanaise ». Memoire du BRGM. Paris 1980, 375p. 
[2] Nzenti J. P., Barbey P., Macaudière J., Soba D., 1988. Origin and evolution of the late Precambrian high-grade Yaoundé gneisses (Cameroon). Precambrian Research, 38, 91-109. https://doi.org/10.1016/0301-9268(88)90086-1.

[3] Ngako V., Jegouzo P., Nzenti J. P., 1992. Champ de raccourcissement et de cratonisation du Nord-Cameroun du paléozoïque supérieur au paléozoïque moyen. Comptes Rendus de l'Académie des Sciences, Paris, 315, 457-463.

[4] Ngako V., Affaton P., Njanko T., 2003. Pan-African tectonique evolution in central and southern Cameroon: Transposition during sinistral shear mouvements. Journal of African Earth Sciences, 36, 207-214. https://doi.org/10.1016/S0899-5362(03)00023-X.

[5] Almeida F. F., Hasui Y., Neves B. B., Fuck R. A., 1981. Brazilian structural provinces. Earth Sciences Review, 17, 1-29. https://doi.org/10.1016/00128252(81)90003-9.

[6] Castaing C., Triboutet C., Feybesse J. L., Chevremont P., 1993. Tectonometamorphic evolution of Ghana, Togo and Benin in the ligth of the PanAfrican / Basiliano orogeny. Tectonophysics, 218, 323-347. https://doi.org/10.1016/0040-1951(93)90322-B.

[7] Neves S. P., Melo S. C., Moura C. A. V., Mariano G., Silva J. M. R., 2004. Zircon Pb-Pb geochronology of the Caruaru area, north-eastern Brazil: temporal constraints on the Proterozoic evolution of Borborema Province. International Geology Review, 46, 52-63. https://doi.org/10.2747/00206814.46.1.52.

[8] Oliveira E. P., Toteu S. F., Araújo M. N. C., Carvalho M. J., Nascimento R. S., Bueno J. F., Mcnaughton N., Basilici G., 2006. Geologic correlation between the Neoproterozoic Sergipano belt (NE Brazil) and the Yaoundé belt (Cameroon, Africa). Journal of African Earth Sciences, $44,470-478$. https://doi.org/10.1016/j.jafrearsci.2005.11.014

[9] Van Schmus W. R., Oliveira E. P., Da Silva Filho A. F., Toteu S. F., Penaye J., Guimarães I. P., 2008. Proterozoic links between the Borborema Province, NE Brazil, and the Central African Fold Belt. Geological Society, London, Special Publication, V. 294, 69-99. https://doi.org/10.1144/SP294.5.

[10] Archanjo C. J., Viegas L. G. F., Hollanda M. H. B. M., Souza L. C., Liu D., 2013. Timing of the HT/LP transpression in the Neoproterozoic Seridó Belt (Borborema Province, Brazil): constraints from U-Pb (SHRIMP) geochronology and implications for the connections between NE Brazil and West Africa. Gondwana Research, 23, 701-714. https://doi.org/10.1016/j.gr.2012.05.005.

[11] Toteu S. F., Penaye J., Poudjom D. Y., 2004. Geodynamic evolution of the Pan-African belt in central Africa with special reference to Cameroon. Canadian Jounal of Earth Sciences, 41, 73-85. https://doi.org/10.1139/e03-079.

[12] Ngako V., Affaton P., Njonfang E., 2008. Pan-African tectonics in northwestern Cameroon: implication for the history of western Gondwana. Gondwana Research, 14, 509-522. https://doi.org/10.1016/j.gr.2008.02.002

[13] Toteu S. F., Van Schmus W. R., Penaye J., Michard A., 2001. New U-Pb and Sm-Nd data from North central Cameroon and bearing on the prepanafrican history of central Africa. Precambrian Research, 67, 45-73. https://doi.org/10.1016/S0301-9268(00)00149-2.

[14] Tchakounte J., Toteu S. F., Van Schmus W. R., Penaye J., Deloule E., Mvondo O. J., Bouyo H. M., Ganwa A. A., White W., 2007. Evidence of Ca $1.6 \mathrm{Ga}$ detrical zircon in the Bafia Group (Cameroun): Implication for the chronostratigraphy of the Pan-African Belt North of the Congo Craton. Comptes Rendus de Géosciences, 339, 132-142. https://doi.org/10.1016/j.crte.2007.01.004

[15] Ganwa A. A., Wolfgang F., Wolfgang S., Shang K. C., Mvondo Ondoa J., Satir M., Tchakounte Numbem J., 2008a. Zircon ${ }^{207} \mathrm{~Pb} /{ }^{206} \mathrm{~Pb}$ evaporation ages of Panafrican métasédimentary rocks in the Kombé-II area (Bafia group Cameroon): constaints on protolith age and provenance. Journal of African Earth Sciences, V. 51, 77-88. https://doi.org/10.1016/j.jafrearsci.2007.12.003.

[16] Njanko T., Nedelec A., Affaton P., 2006. Synkinematic high-K calc-alkaline plutons associated with the Pan-African Central Cameroon shear zone (W-Tibati area): Petrology and geodynamic significance. Journal of Africa Earth Sciences, 44, 494-510. https://doi.org/10.1016/j.jafrearsci.2005.11.016.

[17] Nzenti J. P., Badibanga K., Gerhard W., Ruananza T. L., 2006. Synkinematic emplacement of granitoids in a Pan-African shear zone in Central Cameroon. Journal of African Earth Sciences, 45, 75-76. https://doi.org/10.1016/j.jafrearsci.2006.01.005.

[18] Ganwa A. A., Siebel W., Frisch W., Shang C. K., Ekodeck G. E., 2011c. Geochemistry and geochronology of the Méiganga metadiorite: implications on the timing of D2 deformational phase in Adamawa Yadé Domain in Cameroon. International Journal of Biological and Chemical Sciences, 5(4), 1754-1767. https://doi.org/10.4314/ijbcs.v5i4.37.

[19] Ganwa A. A., Klötzli U. S., Hauzenberger C., 2016. Evidence for Archean inheritance in the pre-Panafrican crust of Central Cameroon: Insight from zircon internal structure and LA-MCICP-MS U-Pb ages. Journal of African Earth Sciences, 120 , 12-22. https://doi.org/10.1016/j.jafrearsci.2016.04.013

[20] Daouda D., Tchameni R., Bascou J., Awe Wangmene S., Fosso Tchunte P. M., Bouchez J. L., 2017. Microstructures and magnetic fabrics of the Ngaoundéré granite pluton (Cameroon): Implications to the late-Pan-African evolution of Central Cameroon Shear Zone. Journal of African Earth Sciences, 129, 887-897. https://doi.org/10.1016/j.jafrearsci.2017.02.027.

[21] Naïmou S., Ganwa A. A., Urs Klötzli., Amadou D. K., Ekodeck G. E., 2014. Petrography and geochemistry of Precambrian basement straddling the Cameroon-Chad border: The Touboro-Baïbokoum area. International Journal of Geosciences, 5, 498-431. https://doi.org/10.4236/ijg.2014.54040.

[22] Toteu S. F., Penaye J., Poudjom D. Y., 2004. Geodynamic evolution of the Pan-African belt in central Africa with special reference to Cameroon. Canadian Journal of Earth Sciences, 41, 73-85. https://doi.org/10.1139/e03-079.

[23] Abdelsalam, M. G., Liégeois, J. P., Stern R. J., 2002. The Saharan Metacraton. Journal of African Earth Sciences, 34, 119-136. https://doi.org/10.1016/S0899-5362(02)00013-1.

[24] Toteu S. F, Yongue Fouateu R, Penaye J., Tchakounte J., Ciriaque S. A., Mouangue, Van Schmus W. R., Deloule E., Stendal H., 2006. U-Pb dating of plutonic rocks involved in the nappe tectonic in southern Cameroon: consequence for the Pan-African orogenic evolution of the central African fold belt. Journal of African Earth Sciences, 44. 479-493. https://doi.org/10.1016/j.jafrearsci.2005.11.015.

[25] Soba D., Michard A., Toteu S. F., Norman D. I., Penaye J., Ngako V., Nze Nti J. P., Dautel D., 1991. Données géochronologiques nouvelles (Rb$\mathrm{Sr}$; U-Pb ; Sm-Nd) sur la zone mobile panafricaine de l'Est Cameroun : Age protérozoïque supérieur de la série de Lom. Comptes Rendus de l'Académie des Sciences, Paris, 315, 1453-1458.

[26] Amadou D. K., Ganwa A. A., Klötzli Urs, Hauzenberger C., Ngounouno I., Naïmou S., 2017. The Pan-African Biotite-Muscovite Granite and Amphibole-Biotite Granite of Doua (Central Cameroon): Zircon Features, LA-MC-ICP-MS U-Pb Dating and Implication on Their Tectonic Setting. Journal of Geosciences and Geomatics, Vol. 5, No. 3, 119-129. https://doi.org/10.12691/jgg-5-3-3.

[27] Toteu S. F., Penaye J., Deschamps Y., Nyama Atibagoua B., Bouyo Houkrtchang M., Sep Nlonmgan J. P., Mbola Ndzama S. P., 2008. Géologie et ressources minérales du Cameroun 1/1000000 33rd. International Congress, Oslo Norway, 6-14.

[28] Ganwa A. A., Wolfgang S., Wolfgang F., Kongnyuy C. S., 2011b. Geochemistry of magmatic rocks and time constraints on deformational phases and shear zone slip in the Méiganga area, central Cameroon. International Geology Review, Vol. 33, $\mathrm{N}^{\circ}$ 7, June 2011, 759-784. https://doi.org/10.1080/00206810903211161.

[29] Ganwa A. A., Wolfgang S., Kongnyuy C. S., Naimou S. and Ekodeck G. E., 2011a. New Constraints from Pb-Evaporation Zircon Ages of the Méiganga Amphibole-Biotite Gneiss, Central Cameroon, on Proterozoic Crustal Evolution. International Journal of Geosciences, 2011,2 , $138-147$. https://doi.org/10.4236/ijg.2011.22014.

[30] Nkouandou O. F., Ngounouno I., Déruelle B., Ohnenstetter D., Montigny R., Damaiffe D., 2008. Pretology of the Mio-Pliocene volcanism to the North and East of Ngaoundere (Adamwa-Cameroon). Comptes Rendus Géosciences, 340, 28-37. https://doi.org/10.1016/j.crte.2007.10.012.

[31] Tchameni R., Pouclet A., Penaye J., Ganwa A. A., Toteu S.F., 2006. Petrography and géochemistry of the Ngaoundéré Pan-African granitoïds in Central Nord Cameroon: implication for their sources and geological setting. Journal of African Earth Sciences 44, 511-529. https://doi.org/10.1016/j.jafrearsci.2005.11.017.

[32] Djouka-Fonkwé M. L., Schulz B., Schüssler U., Tchouankoué J. P., Nzolang, C., 2008. Geochemistry of the Bafoussam Pan-African I- and S-type granitoids in western Cameroon. Journal of African Earth Sciences, 50, 148-167. https://doi.org/10.1016/j.jafrearsci.2007.09.015. 
[33] Ganwa A. A., Wolfgang S., Kongnyuy C. S., Naimou S. and Ekodeck G. E., 2011a. New Constraints from Pb-Evaporation Zircon Ages of the Méiganga Amphibole-Biotite Gneiss, Central Cameroon, on Proterozoic Crustal Evolution. International Journal of Geosciences, 2011, 2, 138-147. https://doi.org/10.4236/ijg.2011.22014.

[34] Ngnotue T., Nzenti J. P., Barbey P., Tchoua F. M., 2000. The Ntui-Bétamba high-grade ngeisses: a Nortward extension of the pan-African Yaoundé gneisses in Cameroon. Journal of African Earth Sciences, 31, 369-381. https://doi.org/10.1016/S0899-5362(00)00094-4.

[35] Cox K. G., Bell J. D., Pankust R. J., 1979. The interpretation of igneous rocks. George Allen \& Unwin. https://doi.org/10.1007/978-94-017-3373-1.

[36] Wilson M., 1989. Igneous Petrogenesis. London: Unwin Hyman, London, 466p. https://doi.org/10.1007/978-1-4020-6788-4.

[37] Le Maitre R. W., 1989. A Classification of Igneous Rocks and Glossary of Terms. Recommendations of the IUGS Commission on the Systematics of Igneous Rocks. Oxford: Blackwell. 193p.

[38] Maniar P. D., Piccoli P. M., 1989. Tectonic Discrimination of Granitoids. The Geological Society of America, 101, 635-643. https://doi.org/10.1130/0016-7606(1989)101<0635:TDOG>2.3.CO;2.

[39] Harker, 1909. The natural history of igneous rocks. Methuen, London.

[40] Mc Donough W. F., Sun S. S. 1995. The composition of the Earth. Chemical Geology, 120, 223-253. https://doi.org/10.1016/0009-2541(94)00140$\underline{4}$.

[41] Miyashiro, A. (1978) Nature of Alkalic Volcanic Rock Series. Contributions to Mineralogy and Petrology, 66, 91-104. https://doi.org/10.1007/BF00376089.

[42] Irvine T. N., Barragar W. R. A., 1971. A guide to the chemical classification of the common volcanic rocks. Canadian Journal of Earth Sciences, 8 , 523-548. https://doi.org/10.1139/e71-055.

[43] Frost B. R., Barnes C. G., Collins W. J., Arculus R. J., Ellis D. J., Frost C. D., 2001. A geochemical classification for granitic rocks. Journal of Petrology, 42, 2033-2048. https://doi.org/10.1093/petrology/42.11.2033.

[44] Pearce J. A., Harris N. B. W., Tindle A. G., 1984. Trace element discrimination diagrams for the tectonic interpretation of granitic rocks. Journal of Petrology, 25, 956-983. https://doi.org/10.1093/petrology/25.4.956.

[45] Harris N. B. W., Pearce J. A., Tindle A. G., 1986. Geochimical characteristics of collision-zone magmatism. In: Coward M. P. and Reis A. C. (eds), Collision tectonics, Geological Society London, Special Publications, 19, 67-81. https://doi.org/10.1144/GSL.SP.1986.019.01.04.

[46] Clemens J. D., Wall V. J., 1981. Origin and crystallization of some peraluminous (S-type) granitic magmas. Canadian Mineralogist, 19, $111-131$.

[47] Liankun S., Kuirong Y., 1989. A two-stage crust-mantel interaction model for mafic microgranular enclaves in the Daning granodiorite pluton, Guangxi, China. In Didier J. and Barbarin B (Eds), Enclaves and granite petrology, Developments in Petrology, 13, Elsevier, 95-110.

[48] Zorpi M. J., Coulon C., Orsini J. B., Cocirta C., 1989. Magma mingling, zoning and emplacement in calc-alkaline granitoid plutons. Tectonophysics, 157, 315-329. https://doi.org/10.1016/0040-1951(89)90147-9.

[49] Haïmeur J., Iz-Eddine E. A. E. H., Chabane A., 2004. Pétrologie et géochimie des granitoïdes calco-alcalins de Zaër (Maroc central) : modèle pétrogénétique. Bulletin de l'Institut Scientifique, Rabat, section Sciences de la Terre, n²6, $27-48$.

[50] Orsini J. B., Cocirta C., Zorpi M. J., 1991. Genesis of mafic microgrenular enclaves trough differentiation of basic magmas, mingling and chemical exchanges with their host granitoïd magma. In Didier J. and Babarin B. (Eds) Enclaves and granite petrology, Developments in Petrology, 13, Elsevier, 445-463.

[51] Rollingson H. R., 1993. Using geochemical data: evaluation, presentation, interpretation. Pearson Education Limited, Essex. 352 p.

[52] Zhu D., Mo X., Wang L., Zhao Z., Niu Y., Zhou C., Yang Y., 2009. Petrogenesis of highly fractionated I-type granites in the Zayu area of eastern Gangdese, Tibet: Constraints from zircon U-Pb geochronology, geochemistry and Sr-Nd-Hf isotopes. Science in China, Series D: Earth Sciences, 52(9), 1223-1239. https://doi.org/10.1007/s11430-009-0132-X.

[53] Davidson J. P., McMillan N. J., Moorbath S., Worner G., Harmon R. S., Lopez-Escobar L., 1990. The Nevados de Payachata volcanic region $\left(18^{\circ} \mathrm{S} / 69^{\circ} \mathrm{W}, \mathrm{N}\right)$ II. Evidence for widespread crustal involvement in Andean magmatism. Contributions to Mineralogy and Petrology, $105,412-432$. https://doi.org/10.1007/BF00286829.

[54] Nomo N. E., Tchameni. R.., Vanderhaeghe O., Barbey P., Fosso Tchunte P. M., Wambo Takodjou J. D., Lemdjou B. Y., Saha Fouotsa A. N., 2015. Petrography and Geochemistry of the Mbip Granitic Massif, SW Tcholliré (Central North Cameroon): Petrogenetic and Geodynamic Implication. International Journal of Geosciences, 6, 761-775. https://doi.org/10.4236/ijg.2015.67062.

[55] Peycru P., Dupin J. M., Fogelgesang J. F., Van D. R. C., Cariou F., Perrier C., Augère B., 2008. Géologie, Tout-En-Un. BCPST. Dunod, Paris, 641 p.

[56] Heinhorst J., Lehmann B., Seltmann S., 1996. New geochemical data on granitic rocks of central Kazakhstan. In Granite-related ore deposits of central Kazakhstan and adjacent areas (eds. V. Shatov, R. Seltmann, A. Kremenetsky, B. Lehmann, V. Popov, and P. Ermolov). Glagol Publishing House, St. Petersburg.

[57] Zoheir B. A., Mehanna A. M., Qaoud N. N., 2008. Geochemistry and geothermobarometry of the Um Eleiga Neoproterozoic island arc intrusive complex, SE Egypt: genesis of a potential gold-hosting intrusion. Applied Earth Sciences: IMM Transactions section B, 117(3), 89-111. https://doi.org/10.1179/174327508X375620.

[58] Taylor S. R., McLennan S. M., 1985. The continental cust: its composition and evolution. Blackwell, 312p.

[59] Rudnick R. L., Fountain D. M., 1995. Nature and composition of the Continental-Crust a Lower Crust perspective. Revue of Geophysics, 33(3), 267309. https://doi.org/10.1029/95RG01302.

[60] Bouyo M. H., Zhao Y., Penaye J., Zhang S. H., Njel, U. O., 2015. Neoproterozoic subduction-related metavolcanic and metasedimentary rocks from the Rey Bouba Greenstone Belt of north-central Cameroon in the Central African Fold Belt: New insights into a continental arc geodynamic setting. Precambrian Research, 21, 40-53. https://doi.org/10.1016/j.precamres.2015.01.012.

[61] Liégeois J. P., Black R., Navez J., Latouche L., 1994. Early and late Pan-African orogenies in the Aïr assembly of terrane (Tuareg shield, Niger). Precambrian Research, 67, 59-88. https://doi.org/10.1016/0301-9268(94)90005-1.

[62] Barbarin B., 1999. A review of the relationships between granitoïd types, their origins and their geodynamic environnments. Lithos, 46, 605-626. https://doi.org/10.1016/S0024-4937(98)00085-1.

[63] Ganwa A. A., Klötzli U. S., Hauzenberger C., 2016. Evidence for Archean inheritance in the pre-Panafrican crust of Central Cameroon: Insight from zircon internal structure and LA-MCICP-MS U-Pb ages. Journal of African Earth Sciences, 120 , $12-22$. https://doi.org/10.1016/j.jafrearsci.2016.04.013.

[64] Pouclet A., Vidal M., Doumnang J. C., Vicat J. P., Tchameni R., 2006. Neoproterozoic crustal evolution in Southern Chad: Pan-African ocean basin closing, arc accretion and late- to post-orogenic granitic intrusion. Journal of African Earth Sciences, 44, 543-560. https://doi.org/10.1016/j.jafrearsci.2005.11.019. 